\title{
An Evaluation of Oral Language: The Relationship between Listening, Speaking and Self-efficacy
}

\author{
Sezgin Demir \\ Faculty of Education, Firat University, Turkey
}

Copyright $\subset 2017$ by authors, all rights reserved. Authors agree that this article remains permanently open access under the terms of the Creative Commons Attribution License 4.0 International License

\begin{abstract}
Listening and speaking skills are fundamental determinants of an individual's academic success. The aim of this research is to establish the relationship between listening and speaking skills, and study how listening predicts and cognitively arranges speaking. The research was carried out using the quantitative pattern in correlational type. The population of the research consists of a randomly chosen sample of 662 secondary school students from the city of Aksaray in Turkey. The data were gathered and analysed using the percentage and frequency techniques and gender variance comparisons were made. Independent group t-tests, and variance analysis were used on grade, parental education status, book reading, TV watching and internet use. To determine the relationship between the variables, Pearson correlation coefficient was used and to determine the predicting relationship, simple linear regression analysis was used. The research found that girls have higher verbal communication skills and that the higher the level of parental education and the more time spent reading books led to an increase in verbal communication skills and self-efficacy, whereas the amount of time spent watching TV and using a computer had a negative effect on self-efficacy. Statistics show that listening skill is a significant predictor of speaking skill.
\end{abstract}

Keywords Language Education, Mother Tanguage, Listening, Speaking, Oral Language, Self-efficacy

\section{Introduction}

Language has a complicated structure and is difficult to define, but we define it as a conventional system with two adjuncts and a fundamental function of communication. The essential difference between oral and written language is that the spoken word is instantaneous and transient with little opportunity to hear what was said again. [1]. Although speaking is involved in expressing and listening is involved in comprehension, speaking and listening must be considered as activities that form the communication process, complete each other and cannot be separated. [2]. Listening and speaking constitute the two elements of oral language, and the existence of listening skills obliges speaking, but in terms of language acquisition listening is prior to speaking. The close relationship between listening and speaking is taken into consideration by researchers in two fundamental ways. Firstly, listening is the cognitive process and interpretation of auditory codes; the semantics. Secondly, listening triggers, supervises and organises speaking [3, 4, 5]. Listening supervises the performance of speaking, and is as important as speaking. If we accept the existence of listening activities during speaking and abstract mental designing during these interpreting processes, we find a layout in the base data ordered in a complex way and we can explain why oral expressions are heard and understood in certain ways in some communication [6]. In addition, auditory feedback disability or disorder, which results from sensory-neurologic hearing handicap, causing failures in the ability of the individual to recognize and correct his or her own speaking deficiencies and mistakes is related to the supervising and regulating activities of speaking [7]. When speaking at a specific speed, expressing an idea possibly changing a narrow verb juncture, the fact that we listen and do not control the choice of the words is a feature of the skill of comprehension, which forms the cognitive side of listening [1]. The listener knows very little about the structure types within the comprehension process of the spoken language and uses the syntactic and semantic knowledge of the language while hearing the speaking input verb by verb [8].

Without adequate listening skills, sustaining learning processes that might be boring in first or foreign language education, does not seem possible [9]. Within the process of language acquisition the necessity for effective listening skills obliges us to reveal whether the students know how to listen or not [10]. Having good pronunciation allows the communication to be easily understood and speaking fluently can contribute to the student's image [12]. In conclusion, listening, recording what is heard and interpretation skills form the basis of speaking performance. 
Listening forms the basis for speaking and is about showing the cognitive side, whereas speaking is about behaviour/performance. For successful communication, it is inevitable to combine listening and speaking education. Listening while providing control of the learning process stimulates students to speak and helps to improve their speaking skills, and their self-control during verbal communication [13].

Another important issue in learning is positive self-perception and belief in success that can affect students' participation in classroom activities and help them avoid deciding that the activities are beyond their abilities [14]. In terms of deep process strategies, the amount and the quality of effort is related to students' self-efficacy in terms of their general cognitive learning interactions with the effective students using more cognitive strategies than those who possess self-efficacy [15]. This helps determine self-efficacy in relation to listening and speaking skills that form verbal communication, the relationship between these skills and how one predicts the other.

\section{Method}

This research was carried out using a scanning type quantity pattern on 705 secondary school students chosen by the stratified sampling method based on grade variables from schools in four education zones within the city centre of Aksaray. A total of 662 students' scales were included in the analysis, of these, 374 were female (56.5\%), 288 were male $(43.5 \%), 171$ were 5 th grade $(25.8 \%), 163$ were 6 th grade, 166 were 7 th grade and 162 were 8 th grade students. Due to some respondents choosing more than one alternative, or leaving some items blank etc., 43 scales were not evaluated.

\subsection{Purpose of the Research}

The purpose of this research is to determine the relationship between the self-efficacy of students regarding their listening and speaking skills, and to establish this. We sought answers to the following questions:

1. Does the self-efficacy of the students regarding oral language differ in terms of gender, classroom, parental education levels, amount of time spent reading, watching TV and using the internet?

2. What is the correlation level between listening and speaking self-efficacies?

3. What is the predicting level of listening self-efficacy for speaking self-efficacy?

\subsection{The Development of the Data Gathering Tool}

Listening Skills Self-Efficacy Scale (LSS): To determine the levels of self-efficacy regarding listening skills a 28 item 5 Likert type draft scale was formed and the content validity was presented for evaluation by five Turkish language teachers who work in the city of Aksaray and five academics who work in the universities of Aksaray, Firat and Hacettepe. Because of the evaluations provided, some items were improved and rearranged, and five items were removed from the scale. For the pre-application carried out with 253 participants using the 23-item draft scale, considering the correlation matrix, it was decided that there were many items above the acceptable relation level, including ( $r>30)$. Matrix determinant value is bigger than .0001 , and multi co-linearity $(r>.80)$ but as none was observed that there was no need to remove them. The KMO value of the scale was .87 and the Barlett test result was 2.045,345 which was significant at .05 levels so it was decided to use exploratory factor analysis. Since the intersection values of all items in the anti-image correlation matrix were above .50 , no items could be removed from the scale. When the Scree Plot graphic was considered with respect to point 2 , in which the eigenvalue line was broken and gained a consistent slope, a Varimax operation was carried out which is one of the (vertical) extracting approaches and because of the factor analysis an item was removed from the scale since it did not have loading value. Since the loading value of all the other items was above .30 , determining that there were no cyclical items whose relation level was lower than .10 , no items were removed from the scale. In LSS the first factor, which consists of 14 items, explains $19.61 \%$ and the second factor, which consists of 8 items explains $20.54 \%$ of the total variance. Both factors explain $40.15 \%$ of the total variance. It can be said that this is adequate for a multidimensional scale. Within the reliability test carried out for the 22 items it was seen that the item-test (total) correlation coefficients changed between .33 and .60 and therefore no items were removed from the scale. For the first 14 items, the factor Cronbach Alpha reliability coefficient was .85 , for the second 8 items the factor was .85 . For the whole scale, the Cronbach Alpha reliability coefficient was .89. The Spearman Brown reliability coefficient was calculated as .86 and the Guttman split half coefficient was .77. Considering all these results it can be said that the LSS scale was reliable.

Speaking Skills Self-Efficacy Scale (SSS): (SSS): To determine the self-efficacy of the students regarding their speaking skills, a 33 item five Likert type draft scale was developed and presented for evaluation by five Turkish language teachers who work in the province of Aksaray and five academics who work in the universities of Aksaray, Firat and Hacettepe, after which five items were removed and some items were improved and rearranged. After the pre-application process using 253 participants regarding the 28 -item draft scale, considering the correlation matrix, it was decided that there were many items above the acceptable relation level including ( $r>30)$, matrix determinant value is bigger than .0001, and multi co-linearity $(r>.80)$ that were not observed therefore there was no need to remove them. The KMO value of the scale was .88 , the Barlett test result was 2.289,458 and these results were significant at .05 levels so it was decided to carry out exploratory factor analysis. Since the intersection values of all items in the anti-image correlation matrix were 
above .50 , no items could be removed from the scale. When the Scree Plot graphic was considered with respect to point 1 , in which the eigenvalue line was broken and gains a consistent slope, it was decided that it was a one dimension scale. Due to the factor analysis, three items were removed from the scale since they were under the threshold load value. Since the item load value of all the other items was above .30 no items were removed from the scale. It was determined that in SSS, 25 items explained $30.26 \%$ of the total variance and this was adequate for a one dimension scale. Within the reliability test carried out for the 25 items it was seen that the item-test (total) correlation coefficients were between .45 and .61 and therefore no items were removed from the scale. The Cronbach Alpha reliability coefficient calculations for the whole scale was .90 , the Spearman Brown reliability coefficient was .86 and the Guttman split half coefficient was .86 , so considering all these results it can be said that the SSS scale was reliable (see attachment).

\subsection{The Analyze of the Data}

Using percentage and frequency techniques for analysis of the personal data of the participants, and comparisons by gender, the independent groups t-test and variance analysis was used in terms of classroom, parental education status, book reading, watching TV and internet use. In addition, to determine the relationship between the variables and to determine the predictor, the Pearson correlation coefficient linear regression analysis was used. To determine the performance level for each, item the categories of "always (5)", "often (4)", "sometimes (3)", "seldom (2)", and "never (1)" were used. To calculate the average the values between 1,00-5,00 were determined as "always: 4.21-5.00", "often: 3.41-4.20", "sometimes: 2.61-3.40", "seldom: 1.81-2.60" and "never: $1.00-1.80$ ".

\section{Findings and Interpretation}

Analysis of the data on the verbal communication skills of the students are found in this section.

In Table 1 it is seen that the self-efficacy perceptions of the students regarding their verbal communication skills does not differ significantly between genders; $[\mathrm{t}(660)=.588$; $\mathrm{p}>0.05]$, girls $(M=3.93)$ and boys $(M=3.90)$ expressed views using the category "often". Regarding listening skills, girls at $(M=3.85)$ and boys at $(M=3.83)$ is almost the same and regarding speaking skills girls $(M=4.00)$ and boys $(M=$ 3.97) chose the category "often", which is also similar. For both listening and speaking and verbal communication skills, it can be said that the self-efficacy of girls was slightly higher than boys.

Table 1. The Results of the T-Test regarding the Verbal Communication Skills of the Students by Gender

\begin{tabular}{|c|c|c|c|c|c|c|c|}
\hline Dimensions & Gender & $\mathbf{n}$ & $\overline{\mathrm{X}}$ & ss & sd & $\mathbf{t}$ & $\mathbf{p}$ \\
\hline \multirow{2}{*}{ Listening Skills } & Female & 374 & 3.85 & .57 & \multirow{2}{*}{660} & \multirow{2}{*}{.416} & \multirow{2}{*}{.68} \\
\hline & Male & 288 & 3.83 & .64 & & & \\
\hline \multirow{2}{*}{ Speaking Skills } & Female & 374 & 4.00 & .55 & \multirow{2}{*}{660} & \multirow{2}{*}{.692} & \multirow{2}{*}{.49} \\
\hline & Male & 288 & 3.97 & .59 & & & \\
\hline \multirow{2}{*}{ Verbal Communication Skills } & Female & 374 & 3.93 & .52 & \multirow{2}{*}{660} & \multirow{2}{*}{.588} & \multirow{2}{*}{.56} \\
\hline & Male & 288 & 3.90 & .58 & & & \\
\hline
\end{tabular}

${ }^{*} \mathrm{p}<.05$

Table 2. The Results of the Variance Analysis regarding Verbal Communication Skills of the Students according to their Grade Levels

\begin{tabular}{|c|c|c|c|c|c|c|c|c|c|c|c|}
\hline Dimensions & Class & n & $\overline{\mathrm{X}}$ & ss & VK & KT & sd & KO & $\mathbf{F}$ & $\mathbf{p}$ & Difference \\
\hline \multirow{5}{*}{ Listening Skills } & $5^{\text {th }}$ grade & 171 & 3.92 & .56 & & & & & \multirow{5}{*}{$4.033^{*}$} & \multirow{5}{*}{.007} & \multirow{5}{*}{$\begin{array}{l}5-6 \\
6-7\end{array}$} \\
\hline & $6^{\text {th }}$ grade & 163 & 3.72 & .63 & Intergroup & 4.211 & 3 & 1.426 & & & \\
\hline & $7^{\text {th }}$ grade & 166 & 3.90 & .61 & \multirow{2}{*}{ In-group } & \multirow{2}{*}{232.585} & \multirow{2}{*}{658} & \multirow{2}{*}{.353} & & & \\
\hline & $8^{\text {th }}$ grade & 162 & 3.83 & .58 & & & & & & & \\
\hline & Total & 662 & 3.84 & .60 & Total & 236.861 & 661 & & & & \\
\hline \multirow{5}{*}{ Speaking Skills } & $5^{\text {th }}$ grade & 171 & 4.15 & .48 & \multirow{2}{*}{ Intergroup } & \multirow{2}{*}{5.975} & \multirow{2}{*}{3} & \multirow{2}{*}{1.992} & \multirow{5}{*}{$6.303 *$} & \multirow{5}{*}{.000} & \multirow{5}{*}{$\begin{array}{l}5-6 \\
5-7 \\
5-8\end{array}$} \\
\hline & $6^{\text {th }}$ grade & 163 & 3.93 & .56 & & & & & & & \\
\hline & $7^{\text {th }}$ grade & 166 & 3.97 & .64 & \multirow{2}{*}{ In-group } & \multirow{2}{*}{207.910} & \multirow{2}{*}{658} & \multirow{2}{*}{.316} & & & \\
\hline & $8^{\text {th }}$ grade & 162 & 3.91 & .57 & & & & & & & \\
\hline & Total & 662 & 3.99 & .57 & Total & 231.885 & 661 & & & & \\
\hline \multirow{5}{*}{$\begin{array}{c}\text { Verbal } \\
\text { Communication } \\
\text { Skills }\end{array}$} & $5^{\text {th }}$ grade & 171 & 4.03 & .48 & \multirow{2}{*}{ Intergroup } & \multirow{2}{*}{4.257} & \multirow{2}{*}{3} & \multirow{2}{*}{1.419} & \multirow{5}{*}{$4.833^{*}$} & \multirow{5}{*}{.002} & \multirow{5}{*}{$\begin{array}{l}5-6 \\
5-8\end{array}$} \\
\hline & $6^{\text {th }}$ grade & 163 & 3.82 & .56 & & & & & & & \\
\hline & $7^{\text {th }}$ grade & 166 & 3.94 & .59 & \multirow{2}{*}{ In-group } & \multirow{2}{*}{193.193} & \multirow{2}{*}{658} & \multirow{2}{*}{.294} & & & \\
\hline & $8^{\text {th }}$ grade & 162 & 3.87 & .53 & & & & & & & \\
\hline & Total & 662 & 3.92 & .55 & Total & 197.450 & 661 & & & & \\
\hline
\end{tabular}


The findings of the variance analysis shown in Table 2 indicate that the verbal communication skills of the students differ significantly between grades; $\left[\mathrm{F}(3-658)=4.833^{*}\right.$; $\mathrm{p}<.05]$. The Scheffe, Tukey and LSD tests indicate that there are differences regarding verbal communication skills among 5th grade $(M=4.03)$, 6th grade $(M=3.82)$ and 8 th grade students $(M=3.87)$. The Scheffe, Tukey and LSD tests indicate that self-efficacy regarding their listening skills differs significantly $\left[\mathrm{F}(3-658)=4.033^{*} ; \mathrm{p}<.05\right]$ and this difference occurred among 6th grade $(M=3.72)$, 5th grade $(M=3.92)$ and 7 th grade students $(M=3.90)$. Similarly the Scheffe, Tukey and LSD tests indicate that students' self-efficacy regarding speaking skills differs significantly [F $(3-658)=6.303 * ; p<.05]$ and this difference occurred among 5 th grade $(M=4.15), 6$ th grade $(M=3.93)$, 7 th grade $(M$ $=3.97)$, and 8 th grade students $(M=3.91)$. The results of the variance analysis indicate that self-efficacy in relation to listening and speaking skills and verbal communication skills was highest in the "often" category in all grades. The research also indicates that the 5th grade students possess higher levels of listening, speaking and verbal communication skills compared to other grades. In secondary schools, the mother language and activity centre education is ignored which is one of the reasons for these findings.

The findings in Table 3 of the variance analysis indicates that self-efficacy in students regarding their verbal communication skills does not differ significantly due to the education status of their mothers [F (3-658) =.994; $\mathrm{p}>.05]$. However, it is seen that where the education level of mothers is higher, the self-efficacy of the students' regarding their verbal communication skills also increases. The variance analysis carried out for self-efficacy regarding listening skills shows that a significant difference did not occur [F (3-658) =1.997*; p>.05], and the Scheffe, Tukey and LSD tests show that the differences occurred between those students in elementary $(M=3.82)$, secondary schools $(M=3.81)$ and universities $(M=4.01)$ whose mothers were graduates. Therefore, it seems that the education status of the mother is an important predictor in terms of self-efficacy regarding students' listening skills. Regarding self-efficacy in relation to speaking skills there was no significant difference relating to the education status of the mother $[\mathrm{F}(3-658)=.366 ; \mathrm{p}>.05]$. Variance analysis results show that students' choose the "often" category concerning self-efficacy in relation to listening and speaking skills and general verbal communication skills in terms of the education status of their mothers. In conclusion, it can be said that students of university graduate mothers possess higher levels of self-efficacy regarding their own verbal communication skills.

Table 3. The Results of the Variance Analysis regarding Verbal Communication Skills of the Students According to the Education Status of their Mothers.

\begin{tabular}{|c|c|c|c|c|c|c|c|c|c|c|c|}
\hline Dimensions & Class & $\mathbf{n}$ & $\bar{X}$ & ss & VK & KT & sd & KO & $\mathbf{F}$ & $\mathbf{p}$ & Difference \\
\hline \multirow{5}{*}{ Listening Skills } & Elementary School & 333 & 3.82 & .58 & \multirow{2}{*}{ Intergroup } & \multirow{2}{*}{2.137} & \multirow{2}{*}{3} & \multirow{2}{*}{.712} & \multirow{5}{*}{1.997} & \multirow{5}{*}{.113} & \multirow{5}{*}{-} \\
\hline & Secondary School & 171 & 3.81 & .64 & & & & & & & \\
\hline & High School & 101 & 3.89 & .62 & \multirow{2}{*}{ In-group } & \multirow{2}{*}{234.724} & \multirow{2}{*}{658} & \multirow{2}{*}{.357} & & & \\
\hline & University & 57 & 4.01 & .53 & & & & & & & \\
\hline & Total & 662 & 3.84 & .60 & Total & 236.861 & 661 & & & & \\
\hline \multirow{5}{*}{ Speaking Skills } & Elementary School & 333 & 3.99 & .56 & \multirow{2}{*}{$\begin{array}{l}\text { Inter } \\
\text { Group }\end{array}$} & \multirow{2}{*}{.357} & \multirow{2}{*}{3} & \multirow{2}{*}{.119} & \multirow{5}{*}{.366} & \multirow{5}{*}{.366} & \multirow{5}{*}{ - } \\
\hline & Secondary School & 171 & 3,98 & .55 & & & & & & & \\
\hline & High School & 101 & 3.96 & .64 & \multirow{2}{*}{ In-Group } & \multirow{2}{*}{213.528} & \multirow{2}{*}{658} & \multirow{2}{*}{.325} & & & \\
\hline & University & 57 & 4.06 & .57 & & & & & & & \\
\hline & Total & 662 & 3.99 & .57 & Total & 231.885 & 661 & & & & \\
\hline \multirow{5}{*}{$\begin{array}{c}\text { Verbal } \\
\text { Communication } \\
\text { Skills }\end{array}$} & Elementary School & 333 & 3.91 & .53 & \multirow{2}{*}{$\begin{array}{l}\text { Inter } \\
\text { Group }\end{array}$} & \multirow{2}{*}{.891} & \multirow{2}{*}{3} & \multirow{2}{*}{.297} & \multirow{5}{*}{.994} & \multirow{5}{*}{.395} & \multirow{5}{*}{ - } \\
\hline & Secondary School & 171 & 3.89 & .56 & & & & & & & \\
\hline & High School & 101 & 3.93 & .60 & \multirow{2}{*}{ In-Group } & \multirow{2}{*}{196.559} & \multirow{2}{*}{658} & & & & \\
\hline & University & 57 & 4.03 & .52 & & & & .299 & & & \\
\hline & Total & 662 & 3.92 & .55 & Total & 197.450 & 661 & & & & \\
\hline
\end{tabular}

${ }^{*} \mathrm{p}<.05$ 
The findings of the variance analysis shown in Table 4 indicate that the verbal communication skills of the students do not differ significantly according to the education status of their fathers $[F(3-658)=2.208 ; p>.05]$. The variance analysis performed in terms of self-efficacy regarding listening skills shows that a significant difference occurred [F (3-658) $=3.724 * ; p<.05]$. The Scheffe, Tukey and LSD tests indicate that the difference is among the students with fathers who graduated, in elementary schools $(M=3.79)$, secondary schools $(M=3.81)$ and universities $(M=4.00)$. It can be said that the education status of the father is an important predictor of students' self-efficacy regarding their listening skills. There was no significant difference relating to the education status of fathers in self-efficacy regarding speaking skills $[\mathrm{F}(3-658)=.740 ; \mathrm{p}>.05]$. Variance analysis indicates that students' self-efficacy regarding their verbal communication skills and listening and speaking skills, were highest as expressed under the category "often", so it can be said that students with fathers who graduated from university possess a higher level of self-efficacy in relation to their own verbal communication skills.

Table 4. The Results of the Variance Analysis Regarding Verbal Communication Skills of the Students According to the Education Status of their Fathers

\begin{tabular}{|c|c|c|c|c|c|c|c|c|c|c|c|}
\hline Dimensions & Class & $\mathrm{n}$ & $\overline{\mathrm{X}}$ & ss & VK & KT & sd & KO & $\mathbf{F}$ & $\mathbf{p}$ & Difference \\
\hline \multirow{5}{*}{ Listening Skills } & $\begin{array}{l}\text { Elementary } \\
\text { School }\end{array}$ & 189 & 3.79 & .57 & \multirow{2}{*}{ Intergroup } & \multirow{2}{*}{3.955} & \multirow{2}{*}{3} & \multirow{2}{*}{1.318} & \multirow{5}{*}{$3.724 *$} & \multirow{5}{*}{.011} & \multirow{5}{*}{$\begin{array}{c}\text { Elementary } \\
\text { School, } \\
\text { Secondary } \\
\text { School-University }\end{array}$} \\
\hline & $\begin{array}{l}\text { Secondary } \\
\text { School }\end{array}$ & 175 & 3.81 & .62 & & & & & & & \\
\hline & High School & 163 & 3.82 & .62 & \multirow{2}{*}{ In-group } & \multirow{2}{*}{232.907} & \multirow{2}{*}{658} & \multirow{2}{*}{.354} & & & \\
\hline & University & 135 & 4.00 & .57 & & & & & & & \\
\hline & Total & 662 & 3.84 & .60 & Total & 236.861 & 661 & & & & \\
\hline \multirow{5}{*}{ Speaking Skills } & $\begin{array}{c}\text { Elementary } \\
\text { School }\end{array}$ & 189 & 3.96 & .54 & \multirow{2}{*}{ Intergroup } & \multirow{2}{*}{.719} & \multirow{2}{*}{3} & \multirow{2}{*}{.240} & \multirow{5}{*}{.740} & \multirow{5}{*}{.528} & \multirow{5}{*}{ - } \\
\hline & $\begin{array}{l}\text { Secondary } \\
\text { School }\end{array}$ & 175 & 3,97 & .57 & & & & & & & \\
\hline & High School & 163 & 4.00 & .56 & \multirow{2}{*}{ In-group } & \multirow{2}{*}{213.166} & \multirow{2}{*}{658} & \multirow{2}{*}{.324} & & & \\
\hline & University & 135 & 4.05 & .61 & & & & & & & \\
\hline & Total & 662 & 3.99 & .57 & Total & 213.885 & 661 & & & & \\
\hline \multirow{5}{*}{$\begin{array}{c}\text { Verbal } \\
\text { Communication } \\
\text { Skills }\end{array}$} & $\begin{array}{c}\text { Elementary } \\
\text { School }\end{array}$ & 189 & 3.88 & .52 & \multirow{2}{*}{ Intergroup } & \multirow{2}{*}{1.968} & \multirow{2}{*}{3} & \multirow{2}{*}{.656} & \multirow{5}{*}{2.208} & \multirow{5}{*}{.086} & \multirow{5}{*}{ - } \\
\hline & $\begin{array}{l}\text { Secondary } \\
\text { School }\end{array}$ & 175 & 3.89 & .56 & & & & & & & \\
\hline & High School & 163 & 3.91 & .55 & \multirow{2}{*}{ In-group } & \multirow{2}{*}{195.482} & \multirow{2}{*}{658} & 297 & & & \\
\hline & University & 135 & 4.02 & .56 & & & & .291 & & & \\
\hline & Total & 662 & 3.92 & .55 & Total & 197.450 & 661 & & & & \\
\hline
\end{tabular}

${ }^{*} \mathrm{p}<.05$

Table 5. The Results of the Variance Analysis regarding Verbal Communication Skills of the Students according to the Duration of their Daily Book Reading

\begin{tabular}{|c|c|c|c|c|c|c|c|c|c|c|c|}
\hline Dimensions & Duration & $\mathbf{n}$ & $\overline{\mathrm{X}}$ & ss & VK & KT & sd & KO & $\mathbf{F}$ & $\mathbf{p}$ & Difference \\
\hline \multirow{5}{*}{ Listening Skills } & $0-29 \mathrm{~min}$ & 119 & 3.62 & .68 & \multirow{2}{*}{ Intergroup } & \multirow{2}{*}{8.976} & \multirow{2}{*}{3} & \multirow{2}{*}{2.992} & \multirow{5}{*}{$8.639 *$} & \multirow{5}{*}{.000} & \multirow{5}{*}{$\begin{array}{c}0-29 \text { and } \\
30-59 \text {, } \\
60-89,90 \\
\text { and more }\end{array}$} \\
\hline & $30-59$ min & 245 & 3.84 & .56 & & & & & & & \\
\hline & $60-89 \mathrm{~min}$ & 212 & 3.93 & .58 & \multirow{2}{*}{ In-group } & \multirow{2}{*}{227.885} & \multirow{2}{*}{658} & \multirow{2}{*}{.346} & & & \\
\hline & 90 and more $\min$ & 86 & 3,97 & .54 & & & & & & & \\
\hline & Total & 662 & 3.84 & .60 & Total & 236.861 & 661 & & & & \\
\hline \multirow{5}{*}{ Speaking Skills } & 0-29 min & 119 & 3.71 & .66 & \multirow{2}{*}{ Intergroup } & \multirow{2}{*}{12.358} & \multirow{2}{*}{3} & \multirow{2}{*}{4.119} & \multirow{5}{*}{$13.450 *$} & \multirow{5}{*}{.000} & \multirow{5}{*}{$\begin{array}{c}0-29 \text { and } \\
30-59, \\
60-89,90 \\
\text { and more }\end{array}$} \\
\hline & $30-59 \min$ & 245 & 4.01 & .55 & & & & & & & \\
\hline & $60-89 \mathrm{~min}$ & 212 & 4.10 & .51 & \multirow{2}{*}{ In-group } & \multirow{2}{*}{201.527} & \multirow{2}{*}{658} & \multirow{2}{*}{.306} & & & \\
\hline & 90 and more $\min$ & 86 & 4.03 & .51 & & & & & & & \\
\hline & Total & 662 & 3.99 & .57 & Total & 213.885 & 661 & & & & \\
\hline \multirow{5}{*}{$\begin{array}{c}\text { Verbal } \\
\text { Communication } \\
\text { Skills }\end{array}$} & $0-29 \min$ & 119 & 3.66 & .63 & \multirow{2}{*}{ Intergroup } & \multirow{2}{*}{10.275} & \multirow{2}{*}{3} & \multirow{2}{*}{3.425} & \multirow{5}{*}{$12.040 *$} & \multirow{5}{*}{.000} & \multirow{5}{*}{$\begin{array}{c}0-29 \text { and } \\
30-59 \text {, } \\
60-89,90 \\
\text { and more }\end{array}$} \\
\hline & $30-59 \mathrm{~min}$ & 245 & 3.92 & .52 & & & & & & & \\
\hline & $60-89 \mathrm{~min}$ & 212 & 4.02 & .51 & \multirow{2}{*}{ In-group } & \multirow{2}{*}{187.175} & \multirow{2}{*}{658} & 294 & & & \\
\hline & 90 and more $\min$ & 86 & 4.00 & .48 & & & & .284 & & & \\
\hline & Total & 662 & 3.92 & .55 & Total & 197.450 & 661 & & & & \\
\hline
\end{tabular}


The findings in Table 5 show that self-efficacy regarding students' verbal communication skills differs significantly in relation to how much time they spent reading books $[\mathrm{F}$ $(3-658)=12.040 * ; p<.05]$. The Scheffe, Tukey and LSD tests indicate that differences occurred between students who had reading durations of 0-29 minutes $(M=3.66)$ and 30-59 minutes $(M=3.92)$; 60-89 minutes $(M=4.02)$ and 90 and more minutes $(M=4.00)$. The variance analysis performed in terms of self-efficacy regarding listening skills shows a significant difference $\left[\mathrm{F}(3-658)=8.639^{*} ; \mathrm{p}<.05\right]$, and the Scheffe, Tukey and LSD tests indicate that the difference occurred between students who have book reading durations of 0-29 minutes $(M=3.62), 30-59$ minutes $(M=3.84), 60-89$ minutes $(M=3.93)$ and 90 and more minutes $(M=3.97)$. A significant difference is seen among students' self-efficacy regarding speaking skills according to their daily book reading durations $\left[\mathrm{F}(3-658)=13.450^{*} ; \mathrm{p}<.05\right]$. All students who participated in the research chose the category "often". The results indicate that a regular habit of book reading and increasing the duration of book reading are important factors in the development of listening, speaking and verbal communication skills.

The variance analysis findings in Table 6 show that self-efficacy related to verbal communication skills in terms of how much time is spent watching TV differs significantly $\left[F(3-658)=3.735^{*} ; \mathrm{p}<.05\right]$. The Scheffe, Tukey and LSD tests show that the difference is between 90 and more minutes $(M=3.86)$, 30-59 minutes $(M=4.05)$, and 60-89 minutes $(M=3.98)$. A significant difference was determined in terms of TV watching duration [F (3-658) $=3.509 * ; p<.05]$. For listening self-efficacies Scheffe, Tukey and LSD tests indicate that the differences occurred between 30-59 minutes $(M=3.98), 60-89$ minutes $(M=3.91)$ and 90 and more minutes $(M=3.78)$. A significant difference was determined in students' self-efficacy in speaking according to how much time was spent watching TV $\left[\mathrm{F}(3-658)=3.053^{*} ; \mathrm{p}<.05\right]$. The Scheffe, Tukey and LSD tests show that the difference is among 30-59 minutes $(M=4.11), 60-89$ minutes $(M=4.05)$ and 90 and more minutes $(=3.93)$. Where there is an increase in the time spent watching TV, there is a negative impact on secondary school students' self-efficacy regarding their verbal communication and listening and watching skills.

The results of the variance analysis in Table 7 shows that students' verbal communication skills self-efficacy differs significantly based on how long they spent each day using the internet; $\left[\mathrm{F}(3-658)=2.738^{*} ; \mathrm{p}<.05\right]$. The Scheffe, Tukey and LSD tests indicate that the difference is in usage between 90 and more minutes $(M=3.85)$ and 30-59 minutes $(M$ $=4.01$ ). In relation to listening self-efficacy there was no significant difference determined related to internet use $[\mathrm{F}$ $(3-658)=1.279 ; \mathrm{p}>.05]$. For speaking self-efficacy, a significant difference is determined $[\mathrm{F}(3-658)=5.219 *$; $\mathrm{p}<.05]$, and the Scheffe, Tukey and LSD tests indicate that the difference is among 0-29 minutes $(M=4.08), 30-59$ minutes $(M=4.09)$ and 90 and more minutes $(M=3.89)$. It can be said that internet use by secondary school students has a negative effect on verbal communication skills self-efficacies.

Table 6. The Results of the Variance Analysis Regarding Verbal Communication Skills of the Students According to the Duration of their Daily TV Watching

\begin{tabular}{|c|c|c|c|c|c|c|c|c|c|c|c|}
\hline Dimensions & Duration & n & $\overline{\mathrm{X}}$ & SS & VK & KT & sd & KO & $\mathbf{F}$ & $\mathbf{p}$ & Difference \\
\hline \multirow{5}{*}{ Listening Skills } & $0-29 \min$ & 70 & 3.88 & .56 & \multirow{2}{*}{ Intergroup } & \multirow{2}{*}{3.730} & \multirow{2}{*}{3} & \multirow{2}{*}{1.243} & \multirow{5}{*}{$3.509^{*}$} & \multirow{5}{*}{.015} & \multirow{5}{*}{$\begin{array}{c}30-59,60-89 \text { and } 90 \\
\text { and more }\end{array}$} \\
\hline & $30-59 \mathrm{~min}$ & 80 & 3.98 & .59 & & & & & & & \\
\hline & $60-89 \mathrm{~min}$ & 162 & 3.91 & .56 & \multirow{2}{*}{ In-group } & \multirow{2}{*}{233.132} & \multirow[b]{2}{*}{658} & \multirow{2}{*}{.354} & & & \\
\hline & $\begin{array}{l}90 \text { and more } \\
\min \end{array}$ & 350 & 3,78 & .62 & & & & & & & \\
\hline & Total & 662 & 3.84 & .60 & Total & 236.861 & 661 & & & & \\
\hline \multirow{5}{*}{ Speaking Skills } & $0-29 \mathrm{~min}$ & 70 & 3.99 & .63 & \multirow{2}{*}{ Intergroup } & \multirow{2}{*}{2.936} & \multirow{2}{*}{3} & \multirow{2}{*}{.979} & \multirow{5}{*}{$3.053 *$} & \multirow{5}{*}{.028} & \multirow{5}{*}{$\begin{array}{c}30-59,60-89 \text { and } 90 \\
\text { and more }\end{array}$} \\
\hline & $30-59 \mathrm{~min}$ & 80 & 4.11 & .62 & & & & & & & \\
\hline & $60-89 \mathrm{~min}$ & 162 & 4.05 & .52 & \multirow[b]{2}{*}{ In-group } & \multirow[b]{2}{*}{210.949} & \multirow[b]{2}{*}{658} & \multirow[b]{2}{*}{.321} & & & \\
\hline & $\begin{array}{l}90 \text { and more } \\
\text { min }\end{array}$ & 350 & 3.93 & .56 & & & & & & & \\
\hline & Total & 662 & 3.99 & .57 & Total & 213.885 & 661 & & & & \\
\hline \multirow{5}{*}{$\begin{array}{c}\text { Verbal Communication } \\
\text { Skills }\end{array}$} & $0-29 \mathrm{~min}$ & 70 & 3.93 & .56 & \multirow{2}{*}{ Intergroup } & \multirow{2}{*}{3.306} & \multirow{2}{*}{3} & \multirow{2}{*}{1.102} & \multirow{5}{*}{$3.735^{*}$} & \multirow{5}{*}{.011} & \multirow{5}{*}{$\begin{array}{c}30-59,60-89 \text { and } 90 \\
\text { and more }\end{array}$} \\
\hline & $30-59 \mathrm{~min}$ & 80 & 4.05 & .58 & & & & & & & \\
\hline & $60-89 \mathrm{~min}$ & 162 & 3.98 & .50 & \multirow[b]{2}{*}{ In-group } & \multirow[b]{2}{*}{194.144} & \multirow[b]{2}{*}{658} & & & & \\
\hline & $\begin{array}{l}90 \text { and more } \\
\text { min }\end{array}$ & 350 & 3.86 & .55 & & & & .295 & & & \\
\hline & Total & 662 & 3.92 & .55 & Total & 197.450 & 661 & & & & \\
\hline
\end{tabular}

$* \mathrm{p}<.05$ 
Table 7. The Results of the Variance Analysis regarding Verbal Communication Skills of the Students depending on the Duration of their Daily Internet Use

\begin{tabular}{|c|c|c|c|c|c|c|c|c|c|c|c|}
\hline Dimensions & Duration & $\mathbf{n}$ & $\overline{\mathrm{X}}$ & ss & VK & KT & sd & KO & $\mathbf{F}$ & $\mathbf{p}$ & Difference \\
\hline \multirow{5}{*}{ Listening Skills } & $0-29$ min & 166 & 3.83 & .61 & \multirow{2}{*}{ Intergroup } & \multirow{2}{*}{1.373} & \multirow{2}{*}{3} & \multirow{2}{*}{.458} & \multirow{5}{*}{1.279} & \multirow{5}{*}{.281} & \multirow{5}{*}{-} \\
\hline & $30-59 \mathrm{~min}$ & 125 & 3.94 & .49 & & & & & & & \\
\hline & $60-89 \mathrm{~min}$ & 154 & 3.84 & .59 & \multirow{2}{*}{ In-group } & \multirow{2}{*}{235.488} & \multirow{2}{*}{658} & \multirow{2}{*}{.358} & & & \\
\hline & 90 and more min & 217 & 3,81 & .65 & & & & & & & \\
\hline & Total & 662 & 3.84 & .60 & Total & 236.861 & 661 & & & & \\
\hline \multirow{5}{*}{ Speaking Skills } & $0-29 \min$ & 166 & 4.08 & .56 & \multirow{2}{*}{ Intergroup } & \multirow{2}{*}{4.971} & \multirow{2}{*}{3} & \multirow{2}{*}{1.657} & \multirow{5}{*}{$5.219 *$} & \multirow{5}{*}{.001} & \multirow{5}{*}{$\begin{array}{c}0-29, \\
30-59 \text { and } \\
90 \text { and } \\
\text { more }\end{array}$} \\
\hline & $30-59 \mathrm{~min}$ & 125 & 4.09 & .48 & & & & & & & \\
\hline & $60-89 \mathrm{~min}$ & 154 & 3.96 & .58 & \multirow{2}{*}{ In-group } & \multirow{2}{*}{208.914} & \multirow{2}{*}{658} & \multirow{2}{*}{.317} & & & \\
\hline & 90 and more min & 217 & 3.89 & .60 & & & & & & & \\
\hline & Total & 662 & 3.99 & .57 & Total & 213.885 & 661 & & & & \\
\hline \multirow{5}{*}{$\begin{array}{c}\text { Verbal } \\
\text { Communication } \\
\text { Skills }\end{array}$} & $0-29 \mathrm{~min}$ & 166 & 3.96 & .55 & \multirow{2}{*}{ Intergroup } & \multirow{2}{*}{2.435} & \multirow{2}{*}{3} & \multirow{2}{*}{.812} & \multirow{5}{*}{$2.738^{*}$} & \multirow{5}{*}{.043} & \multirow{5}{*}{$\begin{array}{c}30-59 \text { and } \\
90 \text { and } \\
\text { more }\end{array}$} \\
\hline & $30-59 \mathrm{~min}$ & 125 & 4.01 & .45 & & & & & & & \\
\hline & $60-89 \mathrm{~min}$ & 154 & 3.90 & .55 & \multirow{2}{*}{ In-group } & \multirow{2}{*}{195.015} & \multirow{2}{*}{658} & 206 & & & \\
\hline & 90 and more min & 217 & 3.85 & .58 & & & & .296 & & & \\
\hline & Total & 662 & 3.92 & .55 & Total & 197.450 & 661 & & & & \\
\hline
\end{tabular}

$* \mathrm{p}<.05$

Table 8. The Results of Correlation Analysis According to the Students' Grades

\begin{tabular}{|c|c|c|c|c|}
\hline Dimensions & Part & $\mathbf{n}$ & Listening Skills & Speaking Skills \\
\hline \multirow{5}{*}{ Listening Skills } & $5^{\text {th }}$ grade & 171 & 1.00 & \\
\hline & $6^{\text {th }}$ grade & 163 & 1.00 & \\
\hline & $7^{\text {th }}$ grade & 166 & 1.00 & \\
\hline & $8^{\text {th }}$ grade & 162 & 1.00 & \\
\hline & Total & 662 & 1.00 & \\
\hline \multirow{5}{*}{ Speaking Skills } & $5^{\text {th }}$ grade & 171 & $.75 * *$ & 1.00 \\
\hline & $6^{\text {th }}$ grade & 163 & $.77 * *$ & 1.00 \\
\hline & $7^{\text {th }}$ grade & 166 & $.81 * *$ & 1.00 \\
\hline & $8^{\text {th }}$ grade & 162 & $.69 * *$ & 1.00 \\
\hline & Total & 662 & $.75 * *$ & 1.00 \\
\hline
\end{tabular}

${ }^{*} \mathrm{p}<.05, * * \mathrm{p}<.01$

The findings in Table 8 show that there is a significant relationship $(\mathrm{p}<.01)$ between the speaking self-efficacy and listening self-efficacy levels of the students in terms of gender. Listening and speaking self-efficacies are positive for girls $(\mathrm{r}=.73, \mathrm{p}<.01)$, boys $(\mathrm{r}=.78, \mathrm{p}<.01)$ and all students $(\mathrm{r}=.75, \mathrm{p}<.01)$. The correlational relation between the listening and speaking self-efficacies of the boys is higher than for the girls.

Table 9. The Results of the Regression Analysis between Listening and Speaking Skills

\begin{tabular}{|c|c|c|c|c|c|c|}
\hline Speaking Skills & n & B & SHB & 及 & t & p \\
\hline Stable & & 1.24 & .10 & & 13.07 & .00 \\
\hline Listening Skills & 662 & .72 & .02 & .75 & 29.42 & .00 \\
\hline $\mathrm{n}=662, \mathrm{R}=.75, \mathrm{R}^{2}=.57, \mathrm{~F}=865.259, \mathrm{p}<.01$ \\
\hline
\end{tabular}

As a result of the simple linear regression analysis carried out to determine the predicting level of listening for speaking, a significant relation is observed between these two variables $(\mathrm{R}=.75, \mathrm{R} 2=.57)$ and it is determined that listening is a predictor of speaking $(\mathrm{F}(1-660)=865.259, \mathrm{p}<.01)$. It can be said that self-efficacy regarding listening skills explains $57 \%$ of self-efficacy for speaking skills. The other $43 \%$ of changes regarding speaking can be explained by other components of verbal communication skills. The significance test of basic predictor variable coefficient $(\mathrm{B}=.72)$ for regression equation also points out that listening skills are important predictors. As a result of the simple linear regression analysis, the regression equation which predicts speaking can be visualized as: Speaking Self-efficacy $=(.72 \times$ Listening Self-efficacy $)+1.24$.

\section{Discussion}

There were no differences in gender variables concerning self-efficacy related to verbal communication skills. However, girls have higher perception levels than boys that can be explained by boys having higher levels of anxiety when speaking in front of others. Research carried out by [16], with university students studying English as a foreign language supports this view. In addition, although a significant difference was not determined $[t=.898, .486$; p>.005]; in terms of gender, it points to males $(M=56.41$, 44.97) having higher levels of anxiety when compared to 
females $(M=52.45,41.63)$. It is determined that the students who have higher levels of anxiety are also anxious about failure and are not inclined to use the learning strategies enough to overcome this [17]. When linguistic anxiety is high, it nurtures anxiety about failure and causes less use of remedial learning strategies. To decrease this anxiety about failure, an encouraging behaviour must be assumed towards students' verbal communication skills, because the more they speak, the more they will gain self-confidence and take risks to develop communication skills in self-directed behaviour [18].

The fact that self-efficacy in relation to verbal communication skills decreases as the class grade increases indicates that linguistic skills in mother language education lessons, especially in the secondary school, are not intense or attentive enough. The effort of performing mother language education through reading and writing communication skills reveals this negative situation. Not paying enough attention to and ignoring listening skills points to two fundamental difficulties which are the effort required to make students understand the process regarding listening skills on their own, and choosing the right environment for teaching listening strategies in the classroom [19]. Language teachers whether in mother language teaching or foreign language teaching must be aware of the belief levels of the students regarding language training [14], otherwise students could be condemned to failure from the outset.

The self-efficacy of the students is closely associated with their high self-confidence, the family environment they grew up in and the educational status of their parents. It is seen that as parental education level increases, there is an increase in self-efficacy regarding verbal communication skills. The research carried out by Brassart and Schelstraete with students at the ages of four and five shows that after pragmatic and sensitive interventions using verbal praise, explanation requests, sensitive labelling, question marks, and reproduction and repetitions performed in the parental language, the verbal communication skills of the children are negatively affected [20]. In research carried out by Holloway, Yamamoto, Suzuki, Mindnich in 2008 with Japanese mothers, it is suggested that mothers who pay more for complementary acts are more educated, they have higher family incomes and their children demand more [21]. This can be explained by higher levels of parental education leading to an increase in financial status which means they can enable their children to take part in academic or social complementary activities, courses etc. and by doing this they provide their children with environments where they can socialize and develop verbal communication skills, especially listening.

Educational research indicates that when language is taught to students using children's literature, they think more critically, become individuals who can solve problems they encounter and have a stronger capacity for relating to real life experiences [22]. Performing four fundamental communication skills integrated with language education activities is important in terms of constituting a model.
Listening and reading both provide models and samples for speaking and writing skills and dialogue and interaction may be useful in improving both listening and reading skills [23]. Literature is important in the teaching of language skills, providing benefits to language education, but speaking, listening, reading and writing should not be taught separately, but should be taught in an integrated manner and teachers should consider these four skills as part of the application of verbal and written language [24]. In the research, the increase in the time spent reading books has a positive effect on listening and speaking skills.

Television with its exciting cartoons, moving images, entertaining theatre, interesting musical tunes and international scientific movies is enchanting for children and attracts their attention with these features [25]. However, this research shows that if the time spent watching TV increases students' self-efficacy regarding all their verbal communication skills are negatively affected. It is known that digital technologies, social media, and time spent in virtual environments and using software applications are attractive to young people and can provide extensive education opportunities across different times and distances [26]. However, in their studies of university students Stankovska, Angelkovska, and Grncarovska, suggest that overuse of the internet may lead to poor performance at school, social isolation, depression and loneliness, and they determined a potential negative relationship between internet use and loneliness $(r=.009, p>.01)$; and between internet addiction and high academic performance $(r=.002, p>.01)$ [27]. This research showed that increases in the duration of internet use have a negative impact on self-efficacy regarding verbal communication skills.

The correlation between self-efficacy regarding listening, and speaking skills which consists of the two dimensions of verbal communication skills, determined that boys have higher levels of relations compared to girls. Also, it is interesting that in terms of grade variables the relationship between listening and speaking skills of 8th grade students were at low levels compared to other grades. The simple linear regression analysis determined that listening skills self-efficacy predicts speaking significantly and explains $57 \%$ of the self-efficacy regarding speaking skills. This supports the thesis concerning listening skills constituting ideational infrastructure regarding speaking and arrangement of speaking cognitively.

\section{Results}

Regarding verbal communication skills, it is determined that girls have higher levels of self-efficacy than boys. In addition, it can be said that 8 th grade students' self-efficacy is quite low regarding verbal communication and significantly different from students in other grades. The higher the level of parental education positively affects self-efficacy regarding verbal communication skills especially listening skills as does an increase in time spent by students reading a book, and the application of children's 
literature reading programmes. However, the increase in time spent watching $\mathrm{TV}$ and using the internet have a negative effect on self-efficacy in relation to verbal communication skills. The research determined that there is a correlation between self-efficacy regarding listening and speaking skills at a high level which is higher in boys than girls. It is seen that the relationship between listening and speaking skills of the 8th grade students are lower when compared to other grades. In conclusion, it can be said that self-efficacy regarding listening skills is a predictor of speaking skills and from this aspect speaking has a regulator function in forming the intellectual substructure of speaking.

\section{Appendix}

\section{Listening and Speaking Skills Self-efficacy Evaluation Form}

Dear students

Using this information, we aim to evaluate your listening and speaking skills, so your views are valuable to us. While completing the questionnaire, you should read each question carefully and choose only one option. The information you provide will only be used for scientific purposes. We thank you for your patience and attention.

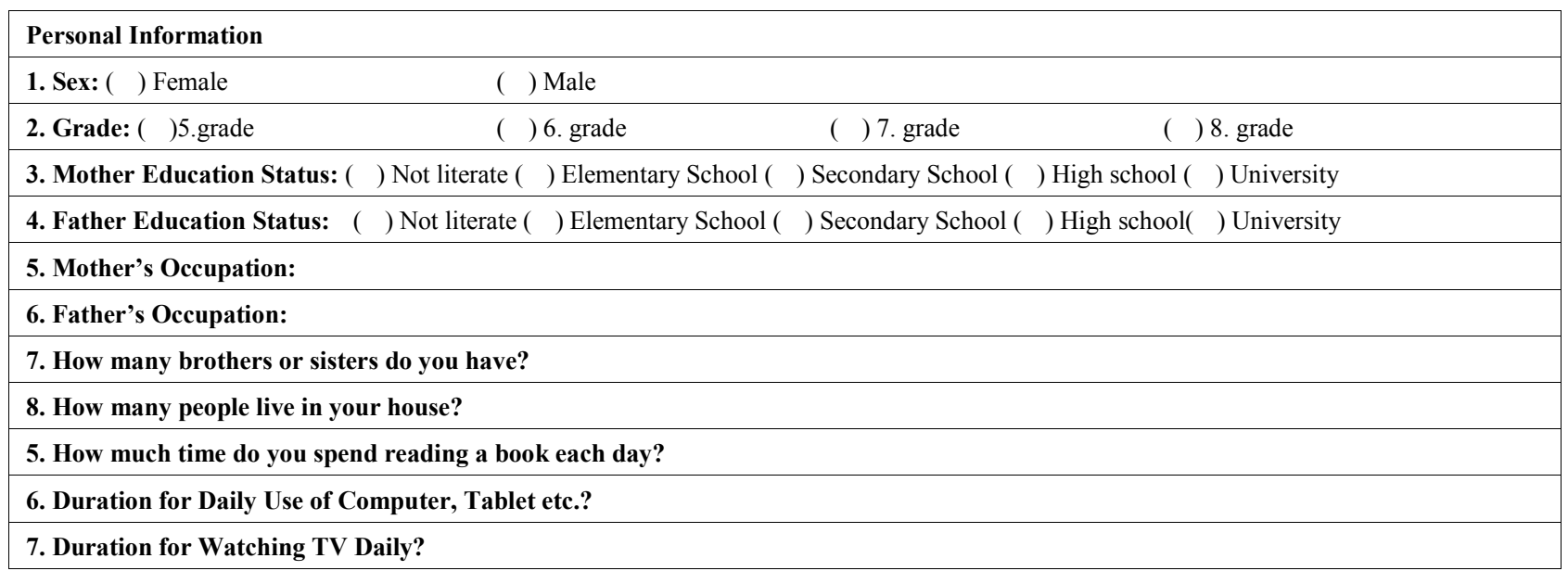

\begin{tabular}{|c|c|c|c|c|c|}
\hline LISTENING SKILLS SELF-EFFICACY SCALE & Always & Frequently & Sometimes & Seldom & Never \\
\hline \multicolumn{6}{|c|}{ 1. Regarding what I listen to, I guess the meaning of words I do not know. } \\
\hline \multicolumn{6}{|c|}{ 2. I do not have difficulty in determining the subject of what I listen to. } \\
\hline \multicolumn{6}{|l|}{ 3. I can determine the main idea of what I listen to. } \\
\hline \multicolumn{6}{|l|}{ 4. I determine the main theme of the poems I listen to. } \\
\hline \multicolumn{6}{|l|}{ 5. I determine the attendant ideas of what I listen to. } \\
\hline \multicolumn{6}{|l|}{ 6. I determine cause and effect relations in what I listen to. } \\
\hline \multicolumn{6}{|l|}{ 7. I determine aim and result relations in what I listen to. } \\
\hline \multicolumn{6}{|c|}{$\begin{array}{l}\text { 8. I do not have difficulty in finding covert/suppressive meanings in what I } \\
\text { listen to. }\end{array}$} \\
\hline \multicolumn{6}{|c|}{ 9. I summarize what I listen to according to the sequence of events. } \\
\hline \multicolumn{6}{|c|}{ 10. I answer accurately to the questions directed concerning what I listen to. } \\
\hline \multicolumn{6}{|c|}{$\begin{array}{l}\text { 11. I distinguish subjective and objective estimations from each other in what } \\
\text { I listen to. }\end{array}$} \\
\hline \multicolumn{6}{|l|}{ 12. I make comparisons regarding what I listen to. } \\
\hline \multicolumn{6}{|c|}{$\begin{array}{l}\text { 13. During listening I put myself in another's place and try to understand his } \\
\text { or her thoughts. }\end{array}$} \\
\hline \multicolumn{6}{|l|}{ 14. I connect visual elements in what I listen to. } \\
\hline \multicolumn{6}{|c|}{ 15. I can distinguish the language difference between poem and text. } \\
\hline \multicolumn{6}{|l|}{ 16. I can connect daily life and what I listen to. } \\
\hline 17. I can determine the related words in what I listen to. & & & & & \\
\hline
\end{tabular}




\begin{tabular}{|l|l|l|l|l|}
\hline 18. I try to learn the expressions in what I listen to (idioms, proverbs etc.) & & & & \\
\hline 19. I enjoy listening to the people who use Turkish language well. & & & & \\
\hline $\begin{array}{l}\text { 20. I would like to join the auditions of my age (panel, conference, concert } \\
\text { etc.) }\end{array}$ & & & & \\
\hline 21. I follow media publications according to my needs. & & & & \\
\hline $\begin{array}{l}\text { 22. I can use different listening methods if necessary (engaged listening, } \\
\text { listening taking notes, listening feeling empathy etc.). }\end{array}$ & & & & \\
\hline
\end{tabular}

\begin{tabular}{|c|c|c|c|c|c|}
\hline SPEAKING SKILLS SELF-EFFICACY SCALE & Always & Frequently & Sometimes & Seldom & Never \\
\hline \multicolumn{6}{|l|}{ 1. I start my speech appropriately. } \\
\hline \multicolumn{6}{|l|}{ 2. I change my speech according to the environment. } \\
\hline \multicolumn{6}{|l|}{ 3. I pay attention to using Turkish words instead of foreign alternatives. } \\
\hline \multicolumn{6}{|l|}{ 4. I arrange my speaking speed in a way that the listener can understand. } \\
\hline \multicolumn{6}{|l|}{ 5. I pay attention to protocols in my speech. } \\
\hline \multicolumn{6}{|l|}{ 6. I can express cause and effect relations in my speech. } \\
\hline \multicolumn{6}{|l|}{ 7. I can express aim and result relations in my speech. } \\
\hline \multicolumn{6}{|l|}{ 8. I end my speech with appropriate expressions. } \\
\hline \multicolumn{6}{|l|}{ 9. I pay attention to breathing correctly (from the diaphragm). } \\
\hline \multicolumn{6}{|l|}{ 10. I speak with a tone of voice that can be easily heard. } \\
\hline \multicolumn{6}{|l|}{ 11. I pay attention for my speech to be understandable. } \\
\hline \multicolumn{6}{|l|}{ 12. I pay attention on emphasis in the right places. } \\
\hline \multicolumn{6}{|l|}{ 13. I pay attention to intonation in my speech. } \\
\hline \multicolumn{6}{|l|}{ 14. I pause in the right places. } \\
\hline \multicolumn{6}{|l|}{ 15. I speak with my own voice without imitating anyone. } \\
\hline \multicolumn{6}{|l|}{ 16. I use body language effectively in my speech. } \\
\hline \multicolumn{6}{|l|}{ 17. I make eye contact with my listeners. } \\
\hline \multicolumn{6}{|l|}{ 18. I pay attention to speaking within the frame of a main idea. } \\
\hline \multicolumn{6}{|l|}{ 19. I use assistant ideas to support my main idea. } \\
\hline \multicolumn{6}{|l|}{ 20. I use figures of speech to increase the effect of my speech. } \\
\hline \multicolumn{6}{|l|}{ 21. I give accurate answers to the questions directed to me. } \\
\hline \multicolumn{6}{|l|}{ 22. I avoid giving distracting details in my speech. } \\
\hline \multicolumn{6}{|l|}{$\begin{array}{l}\text { 23. I pay attention to completing my speech in a time frame that does not bore } \\
\text { listeners. }\end{array}$} \\
\hline \multicolumn{6}{|l|}{ 24. I can express my ideas verbally without hesitation. } \\
\hline 25. I pay attention to use the new words I have learned in my speech. & & & & & \\
\hline
\end{tabular}

Please write below any problems and difficulties you have relating to your speaking and listening skills.

\section{REFERENCES}

[1] Xu, F. (2011). The Priority of Listening Comprehension over Speaking in the Language Acquisition Process, International Education Studies. Vol. 4, No. 1; February 2011, p. 161-165.

[2] Emiroğlu, S. \& Pınar, F. N. (2013). Dinleme Becerisinin Diğer Beceri Alanları ile İlişkisi / Relationshio Between Listening and Other Skill Types, Turkish Studies - International Periodical For The Languages, Literature and History of Turkish or Turkic. Vol. 8/4 Spring 2013, p. 769-782.
[3] Richards, J. C. (2008). Teaching Listening and Speaking: From Theory to Practice. New York, NY: Cambridge University Press.

[4] Buck, G. (2001). Assessing Listening. Cambridge, UK: Cambridge University Press.

[5] Erickzon, D. A. C. (2015). The Relationship Between Listening Proficiency and Speaking Improvement in Higher education: Considerations in Assessing Speaking and Listening, Higher Learning Research Communications. 5(2), p. 34-56. http://dx.doi.org/10.18870/hlrc.v5i2.236.

[6] Chomsky, N. (2002). Dil ve Zihin. Çev. Ahmet Kocaman. Ayraç, Ankara. 
[7] Girgin, M. C. (2008). Speech Rates of Turkish Prelingually Hearing-Impaired Children, International Journal of Special Education. Vol. 23, No. 2, 2008, p. 27-32.

[8] Tyler, L. K. \& Warren, P. (1987). Local and Global Structure in Spoken Language Comprehension, Journal of Memory and Language. 26, p. 638-657.

[9] Bozargian, H. (2012). The Relationship between Listening and Other Language Skills in International English Language Testing System, Theory and Practice in Language Studies. Vol. 2, No. 4, p. 657-663, April 2012.

[10] Feyten, C. M. (1989). Listening Ability: An Overlooked Dimension of Foreign Language Acquisition. http://files.eric.ed.gov/fulltext/ED304002.pdf

[11] Lin, C. Y. (2014). Perception and Production of Five English Front Vowels by College Students, English Language Teaching. Vol. 7, No. 9; 2014, ISSN 1916-4742, E-ISSN 1916-4750, p. 14-20.

[12] Khodaday, E. \& Shamsaee, S. (2012). Formulaic Sequences and Their Relationship with Speaking and Listening Abilities, English Language Teaching. Vol. 5, No. 2; February 2012, p. $39-49$.

[13] Kondreteva, İ. G., Safina, M. S., Valeev, A. A. (2016). Listening as a Method of Learning a Foreign Language at the Non-Language Faculty of the University. International Journal of Environmental \& Science Education. 2016, 11(6), 1049-1058.

[14] Wang, T. \& Rajprasit (2015). Identifying Affirmative Beliefs about English Language Learning: Self-Perceptions of Thai Learners with Different Language Proficiency, English Language Teaching. Vol. 8, No. 4; 2015 ISSN 1916-4742 E-ISSN 1916-4750 Published by Canadian Center of Science and Education.

[15] Çubukçu, F. (2008). A Study On The Correlation Between Self Efficacy And Foreign Language Learning Anxiety. Journal of Theory and Practice in Education. 2008, 4 (1):148-158, ISSN: 1304-9496.

[16] Bozavli, E. \& Gulmez, R. (2012). Turkish Students' Perspectives on Speaking Anxiety in Native and Non-native English Speaker Classes. US-China Education Review. B 12 (2012) 1034-1043 Earlier title: US-China Education Review, ISSN 1548-6613.

[17] Nishitani, M. \& Matsuda, T. (2011). The Relationship Between Language Anxiety, Interpretation of Anxiety, Intrinsic Motivation and the Use of Learning Strategies. US-China Education Review. B 3 (2011) 438-446 Earlier title: US-China Education Review, ISSN 1548-6613.

[18] Lewis, S. (2011). Are Communication Strategies Teachable?. Encuentro. 20, 2011, ISSN 1989-0796, p. 46-54.
[19] Bozargian, H. \& Pillay, H. (2013). Enhancing Foreign Language Learning through Listening Strategies Delivered in L1: An Experimental Study. International Journal of Instruction. January 2013, Vol.6, No.1. e-ISSN: 1308-1470, p-ISSN: 1694-609X, www.e-iji.net.

[20] Brassart, E. \& Schelstraete (2015). Simplifying Parental Language or Increasing Verbal Responsiveness, What is the Most Efficient Way to Enhance Pre-schoolers' Verbal Interactions?. Journal of Education and Training Studies. Vol. 3, No. 3; May 2015 ISSN 2324-805X E-ISSN 2324-8068 Published by Redfame Publishing URL: http://jets.redfame.com

[21] Holloway, S., D.; Yamamoto, Y., Suzuki, S., Mindnich, J., D. (2008). Determinants of Parental Involvement in Early Schooling: Evidence from Japan. ECRP. Vol 10 No 1. Determinants of Parental Involvement in Early Schooling: Evidence from Ja... Page 2 of 10. http://ecrp.uiuc.edu/v10n1/holloway.html

[22] Abdelhalim, S., M. (2015). Children Literature Based Program for Developing EFL Primary Pupils' Life Skills and Language Learning Strategies. English Language Teaching. Vol. 8, No. 2; 2015 ISSN 1916-4742 E-ISSN 1916-4750 Published by Canadian Center of Science and Education

[23] Wu, S. \& Alrabah, S. (2014). Tapping the Potential of Skill Integration as a Conduit for Communicative Language Teaching. English Language Teaching. Vol. 7, No. 11; 2014 ISSN 1916-4742 E-ISSN 1916-4750 Published by Canadian Center of Science and Education.

[24] Babaee, R. \& Yahya, W. R. Bt. W. (2014). Significance of Literature in Foreign Language Teaching. International Education Studies. Vol. 7, No. 4; 2014 ISSN 1913-9020 E-ISSN 1913-9039 Published by Canadian Center of Science and Education.

[25] Yaseen, M. B., Algadi, H. M., Al-Barri, Q., Yaseen, O. B. (2016). The Effectiveness of Televised Children Programs in the Linguistic Development of Kindergarten Children from Teachers' Viewpoints. Journal of Education and Practice. www.iiste.org ISSN 2222-1735 (Paper) ISSN 2222-288X (Online) Vol.7, No.14, 2016.

[26] Li, J., Snow, C., White, C. (2015). Urban adolescent students and technology: access, use and interest in learning language and literacy. Innovation in Language Learning and Teaching. 2015 Vol. 9, No. 2, 143-162, http://dx.doi.org/10.1080/17501229.2014.882929.

[27] Stankovska, G., Angelkovska, S., Grncarovska, S. P. (2016). Social Networks Use, Loneliness and Academic Performance among University Students. Education Provision to Every One: Comparing Perspectives from Around the World BCES Conference Books, 2016, Volume 14, Number 1. 